\title{
Peningkatan Kompetensi Keilmuan IOT Melalui Pelatihan Pengontrolan Perangkat IOT dengan Menggunakan Smartphone untuk Siswa SMK dan SMA di Kota Malang
}

\author{
Dahnial Syauqy ${ }^{* 1}$, Yuita Arum Sari², Putra Pandu Adikara3 ${ }^{3}$, Muhammad Aminul Akbar ${ }^{4}$, Hurriyatul \\ Fitriyah $^{5}$ \\ 1,5Program Studi Teknik Komputer, Fakultas Ilmu Komputer, Universitas Brawijaya \\ 2,3,4 Program Studi Teknik Informatika, Fakultas Ilmu Komputer, Universitas Brawijaya \\ *e-mail: $\underline{\text { dahnial87@ub.ac.id }}{ }^{1}$
}

\begin{abstract}
The internet has encouraged the emergence of a new paradigm in the use of computing, marked by the emergence of devices that are connected to each other or known as the Internet of Things (IoT). One of the factors that contributed to the rapid emergence of "things" in the IoT network was the rapid development of chip technology and also increasingly varied wireless communication technology. With the emergence of the phenomenon of the development of IoT, especially those involving entrepreneurial opportunities in related fields, it is considered important to be introduced early on to students of vocational-high school equivalents in Indonesia. The activity was held in September 2019 at Filkom UB involving 41 participants from 6 schools of vocational-high school or equivalent. The activity succeeded in increasing the participant's understanding of the theory and also the practice of IoT where the participants' pre-test and post-test scores increased from an average of 61.6 to 92.9. The implementation of the activity was also declared successful from the results of the questionnaire. From a total of 425 answers, there were 17 STS answers, 39 TS answers, 205 S answers and 164 SS answers. Taking into account the positive and negative components, a recapitulation of 415 answers (98\%) was found to be satisfied with the implementation of the activities.
\end{abstract}

Keywords: Internet of Things, Android, Vocational High School (SMK), Senior High School (SMA)

\begin{abstract}
Abstrak
Internet mendorong munculnya paradigma baru dalam pemanfaatan komputasi, ditandai dengan kemunculan perangkat yang terhubung satu sama lain atau dikenal dengan Internet of Things (IoT). Salah satu faktor yang mendorong pesatnya kemunculan "things" dalam jejaring IoT tersebut adalah perkembangan teknologi chip dan juga teknologi komunikasi nirkabel yang semakin bervariasi. Dengan kemunculan fenomena perkembangan IoT tersebut, khususnya yang melibatkan peluang wirausaha, dipandang penting untuk dikenalkan sejak dini kepada siswa-siswi SMK-SMA di Indonesia. Kegiatan dilaksanakan pada September 2019 di Filkom UB dengan melibatkan 41 peserta dari 6 sekolah SMK-SMA sederajat. Kegiatan berhasil meningkatkan pemahaman peserta perihal teori dan praktek IoT dimana terlihat nilai-pre-test dan post-test peserta meningkat dari rata-rata 61.6 menjadi 92.9. Pelaksanaan kegiatan juga dinyatakan berhasil dilihat dari hasil kuisioner. Dari total 425 jawaban, terdapat 17 jawaban STS, 39 TS, 205 S dan 164 SS. Dengan memperhitungkan komponen positif dan negatif, didapatkan rekapitulasi sebesar 415 jawaban (98\%) menilai puas pada penyelenggaraan kegiatan.
\end{abstract}

Kata kunci: Internet of Things, Android, Sekolah Menengah Kejuruan (SMK), Sekolah Menengah Atas (SMA)

\section{PENDAHULUAN}

Internet merupakan sebuah teknologi di bidang komputer yang dimanfaatkan secara luas (Deborah Fallows, 2004). Melalui teknologi internet, manusia dapat berkomunikasi kapanpun, di manapun, dan dengan siapapun. Saat ini, internet telah mendorong munculnya paradigma baru dalam segi pemanfaatan komputasi, yang salah satunya ditandai dengan kemunculan perangkat yang terhubung satu sama lain atau dikenal dengan Internet of Things (IoT). Rose dkk. menyampaikan definisi secara umum Internet of Things (IoT) yang diartikan sebagai sebuah skema dimana jejaring dan komputasi dapat secara integratif menjangkau berbagai macam obyek seperti sensor dan peralatan sehari-hari, dimana dengan skema tersebut dapat menghasilkan, 
mempertukarkan dan mengkonsumsi data dengan intervensi manusia seminimal mungkin (Rose et al., 2015).

Secara statistik, Cisco menguraikan bahwa tren ke depan hingga 2020, terdapat peningkatan perangkat komputasi non PC yang dikenal dengan istilah "things" terhadap keseluruhan perangkat komputasi yang ada yang di dalamnya juga termasuk perangkat smartphone, laptop, maupun PC. Tentu, perkembangan yang signifikan tersebut bukan tanpa sebab maupun faktor lain (Afshar, 2017). Salah satu faktor yang turut mendorong pesatnya kemunculan "things" dalam jejaring IoT tersebut adalah pesatnya perkembangan teknologi chip dengan ukuran semakin kecil dan juga teknologi komunikasi nirkabel yang semakin bervariasi. Saat ini telah banyak dijumpai jenis-jenis mikrokontroler maupun mikrokomputer yang ada di pasar. Selain itu, produsen juga seakan berlomba memunculkan berbagai macam tipe sensor dan juga tipe modul komunikasi nirkabel yang pada akhirnya mempermudah pengembang sistem untuk memilih sesuai kebutuhan spesifik yang dirancang. Hal tersebut memicu munculnya banyak maker dan hobbyist yang menghasilkan pembuatan perangkat IoT secara mandiri dan mengandalkan kreativitas.

Saat ini telah banyak teknologi yang membantu mewujudkan kreasi dari yang sebelumnya dirasa hanya untuk produksi industri. Banyaknya pembuatan perangkat IoT mandiri oleh makers maupun hobbyist yang disampaikan sebelumnya, tentu membuka peluang wirausaha di bidang pengembangan perangkat IoT. Apalagi, saat ini telah banyak muncul berbagai situs pemodal crowdfunding semacam kickstarter dan lain sebagainya. Perangkat IoT yang diwujudkan berupa perangkat tertanam dengan kemampuan berkomunikasi dengan internet umumnya dapat dimonitor maupun dikontrol dengan media komputer dari jarak jauh. Saat ini telah banyak sekali produk-produk smarthome yang notabene adalah perangkat IoT yang dapat dikontrol, salah satunya melalui Smartphone (Kumar \& Lee, 2014). Dalam hal ini, Google melalui Android pun tidak melewatkan kesempatan tersebut. Saat ini Google juga telah mengembangkan perangkatnya, seperti Google Home yang terintegrasi dengan smartphone Android (Mtshali \& Khubisa, 2019).

Dengan kemunculan fenomena perkembangan IoT tersebut, khususnya yang melibatkan peluang wirausaha di bidang terkait (Lukman, 2015), tentu dipandang penting untuk dapat dikenalkan sejak dini kepada siswa-siswi Sekolah Menengah Kejuruan (SMK) maupun Sekolah Menengah Atas (SMA) di Indonesia. Diharapkan dengan memiliki kompetensi dibidang pengembangan perangkat IoT, para siswa memiliki kompetensi alternatif bidang IoT yang dapat digunakan sebagai bekal siswa untuk berwirausaha di bidang tersebut. Selain itu, khusus dalam kurikulum 2013 bidang C3 untuk SMK juga terdapat silabus untuk produk kreatif dan kewirausahaan yang mana pengembangan perangkat IoT dapat menjadi salah satu alternatifnya. Sebelumnya, telah banyak dilakukan pengabdian masyarakat di SMA-SMK baik melibatkan yang guru (Guntoro et al., 2017; Nuris, 2018) maupun siswa (Dharmawati, 2020). Terlebih, juga ada beberapa kegiatan yang telah berfokus pada pengenalan keilmuan IoT (Ginanjar Wiro Sasmito, 2020). Hanya saja, siswa-siswi SMA-SMK tentu akan lebih mengena jika pembelajaran dilakukan dengan berupa praktik menggunakan perangkat sekaligus mengenalkan update teknologi kepada mereka.

Dengan latar belakang tersebut, tim pengabdian masyarakat dari FILKOM UB mengadakan kegiatan pelatihan dengan outcome berupa peningkatan kompetensi keilmuan IoT untuk pengontrolan perangkat IoT menggunakan smartphone Untuk Siswa SMA-SMK dan sederajat. Dengan kegiatan ini, diharapkan siswa SMA-SMK maupun sederajat dapat memiliki pengetahuan untuk memanfaatkan teknologi di bidang IoT.

\section{METODE}

Kegiatan pengabdian ini diawali dengan melakukan observasi ke SMK atau SMA sederajat yang menjadi calon mitra untuk memperoleh informasi terkait kebutuhan dari pihak mitra 
beserta spesifikasinya dan meminta kesediaan untuk menjadi mitra pengabdian. Siswa dan siswi pada Sekolah tersebut akan menjadi peserta pelatihan pengontrolan perangkat IoT menggunakan smartphone dengan Google Assistant. Dalam Sub bab ini akan dijelaskan mengenai tahap kegiatan, metode pelatihan serta metode evaluasi kegiatan pengabdian masyarakat yang telah dilakukan.

\subsection{Tahap-tahap kegiatan pengabdian masyarakat}

Secara umum terdapat tiga tahap utama dalam pelaksanaan kegiatan pengabdian ini, yaitu tahap persiapan, tahap pelaksanaan dan tahap penyusunan laporan akhir dan evaluasi. Berikut penjelasan tahap-tahap pelaksanaaan pengabdian:

\subsubsection{Tahap Persiapan dan survei}

Tahap persiapan yang dilakukan untuk melaksanakan program ini meliputi:

a. Survei tempat pelaksanaan kegiatan.

b. Pembuatan proposal dan menyelesaikan administrasi perijinan pada instansi yang akan dilibatkan pada pelaksanaan kegiatan.

c. Pembuatan modul pelatihan pembuatan sistem IoT.

d. Pembuatan jadwal untuk mempertemukan antara pihak SMA-SMK dengan tim pengabdian untuk melakukan pelatihan pembuatan sistem IoT.

\subsubsection{Tahap Pelaksanaan Kegiatan pelatihan}

Kegiatan pengabdian dilaksanakan di laboratorium komputer Fakultas Ilmu Komputer Universitas Brawijaya dengan mengundang perwakilan siswa SMA-SMK di Malang.

\subsubsection{Tahap penyusunan laporan akhir dan evaluasi}

Tahap akhir terdiri dari evaluasi dan pembuatan laporan hasil kegiatan

\subsection{Metode pelatihan}

Secara umum, metode pelatihan yang digunakan dalam kegiatan pengabdian ini adalah metode ceramah dan dilanjutkan dengan praktik secara individu maupun berkelompok. Praktik yang dimaksudkan adalah mengoperasikan dan mengimplementasikan perangkat IoT menggunakan hardware NodeMCU yang diintegrasikan dengan Blynk dan IFTTT yang kemudian akan dikontrol melalui smartphone menggunakan Google Assistant. Untuk dapat merealisasikan pelatihan dengan metode tersebut, digunakan fasilitas berupa laboratorium berisi sejumlah komputer untuk media pembelajaran. Selain itu, peserta akan diberi modul pelatihan dalam bentuk hard copy maupun soft copy.

\subsection{Metode evaluasi}

Proses evaluasi kegiatan pengabdian dilakukan dengan menguji peserta berupa pre-test dan post-test. Pre-test dan post-test berkaitan dengan pengetahuan tentang pembuatan sistem IoT, khususnya yang melibatkan kontrol dari perangkat smartphone. Sebagai evaluasi, juga digunakan kuesioner untuk pengambilan feedback mengenai kegiatan pelatihan yang dilakukan untuk memberikan masukan atas pelaksanaan pelatihan ini.

Sebelum pelaksanaan pelatihan, peserta diminta untuk mengisi pre-test yang berisi tentang pengetahuan awal mereka tentang materi pelatihan. Pada akhir pelaksanaan pelatihan, peserta diminta kembali untuk mengisi post-test yang berisikan pengetahuan tentang materi yang telah didapatkan dari pelatihan. Pada pre-test dan post-test diberikan sejumlah soal yang sama sehingga dapat dilihat apakah dalam pelatihan yang diberikan dapat meningkatkan pengetahuan dan kemampuan peserta. 


\section{HASIL DAN PEMBAHASAN}

Bab ini mendeskripsikan mengenai pelaksanaan kegiatan serta hasil yang didapat selama proses kegiatan berlangsung. Pelatihan ini diikuti oleh 41 peserta dari 7 sekolah sederajat SMA di Malang. Setiap sekolah mengirimkan 3-5 siswa yang didampingi oleh 1 pendamping. Mitra sekolah yang mengikuti kegiatan yakni:

1) SMKN 5 Malang

2) SMKN 4 Malang

3) SMK Telkom Malang

4) SMKN 2 Malang

5) MAN 2 Malang

6) SMAN 3 Malang

7) SMKN 12 Malang

Kegiatan Pelatihan dilaksanakan pada hari Minggu tanggal 8 September 2019. Kegiatan pelatihan bertempat di Lab Komputer Gedung B Fakultas Ilmu Komputer UB. Untuk Pelaksanaan kegiatan pelatihan, juga dilibatkan beberapa mahasiswa yang berperan sebagai panitia lapangan untuk menyiapkan fasilitas untuk mendukung pelaksanaan kegiatan. Agenda dan rundown kegiatan ditampilkan pada Tabel 1.

Tabel 1. Jadwal kegiatan pelatihan

$$
\text { Jam }
$$

Kegiatan

\begin{tabular}{ll}
\hline $06.30-07.30$ & Pengarahan panitia (briefing) dan persiapan \\
\hline $07.30-08.00$ & Registrasi peserta dan pembagian kit \\
\hline $08.00-08.10$ & Pembukaan acara \\
\hline $08.10-12.00$ & Materi IoT dan workhsop \\
\hline $12.00-12.20$ & Games \\
\hline $12.20-12.45$ & Makan siang dan penutupan acara \\
\hline
\end{tabular}

Sebagai outcome dari konten materi dan workshop adalah peserta dapat memahami, menerapkan dan mengaplikasikan teknologi pengontrolan perangkat IoT menggunakan smartphone melalui Google Assistant yang lebih praktis, efektif dan efisien sehingga membuat produktivitas meningkat dan menghemat waktu dan biaya. Para peserta akan mendapatkan pengetahuan dan pengalaman merancang dan membuat perangkat IoT beserta pengontrolan menggunakan smartphone dengan Google Assistant yang meliputi:

a) Pengenalan secara umum mengenai IoT,

b) Pengenalan secara umum mengenai Google assistant,

c) Pengenalan secara umum mengenai NodemCU, Blynk dan IFTTT

d) Perancangan kontrol NodeMCU dengan Blynk

e) Perancangan koneksi dengan IFTTT

f) Pengujian pengontrolan perangkat NodeMCU dengan Google Asistant via koneksi internet

Ipteks ditransfer kepada peserta dalam bentuk pembuatan modul pembelajaran untuk penerapan teknologi serta berupa pelatihan kepada siswa yang terkait. Dokumentasi sesi pelatihan ditunjukkan pada Gambar 1(a), sesi workshop ditunjukkan pada gambar 1(b), salah satu hardware yang dipakai peserta dalam workshop ditunjukkan pada Gambar 1(c), sesi diskusi dan tanya jawab ditunjukkan dalam Gambar 1(d), serta sesi foto bersama dalam Gambar 1(e).

\subsection{Hasil Evaluasi Keberhasilan Pembelajaran}

Evaluasi pelatihan dilakukan untuk mengetahui apakah pembelejaran telah meningkatkan pemahaman dan ketrampilan peserta di bidang IoT. Evaluasi dilakukan dengan 
memberikan pre-test dan post-test yang kemudian dilakukan analisis seberapa besar peningkatan keilmuan yang diperoleh dari kegiatan pelatihan.

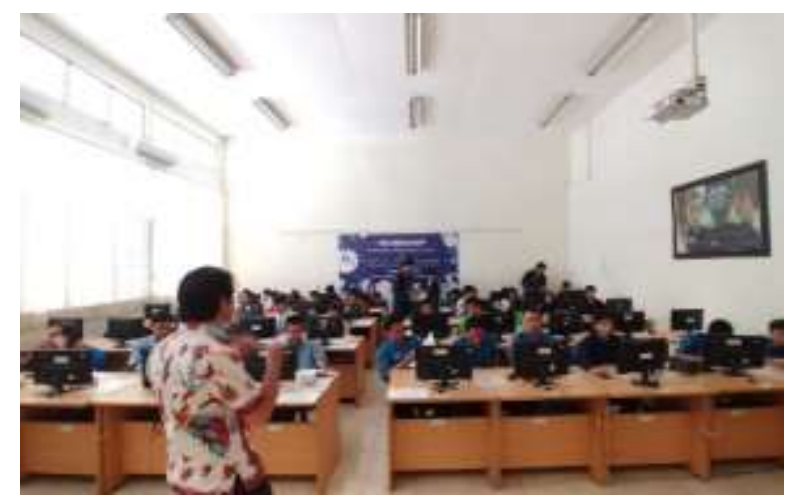

(a)

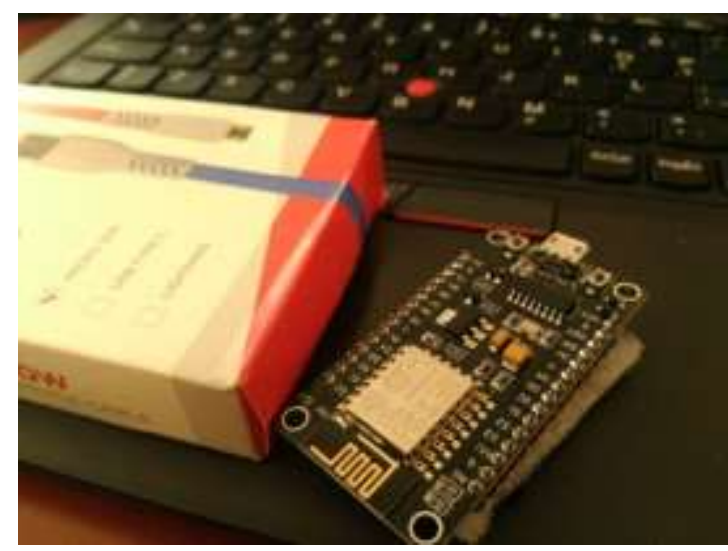

(c)

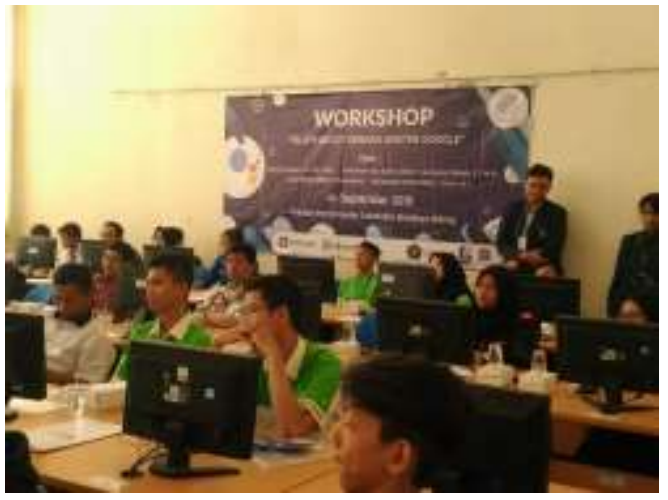

(b)

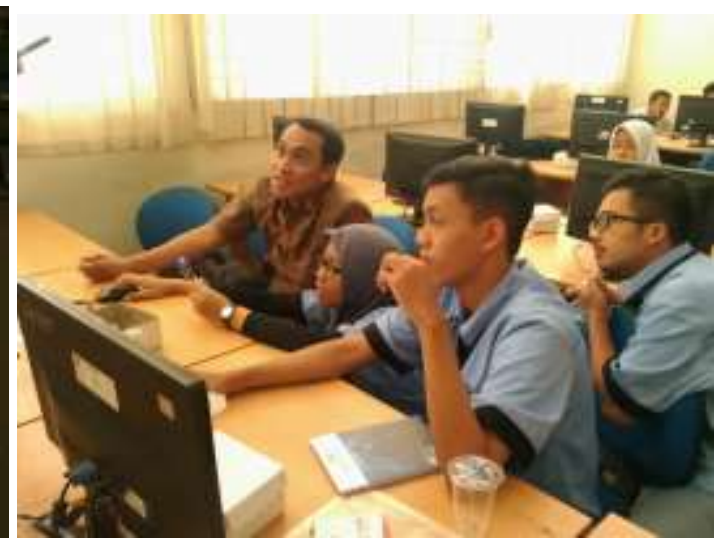

(d)

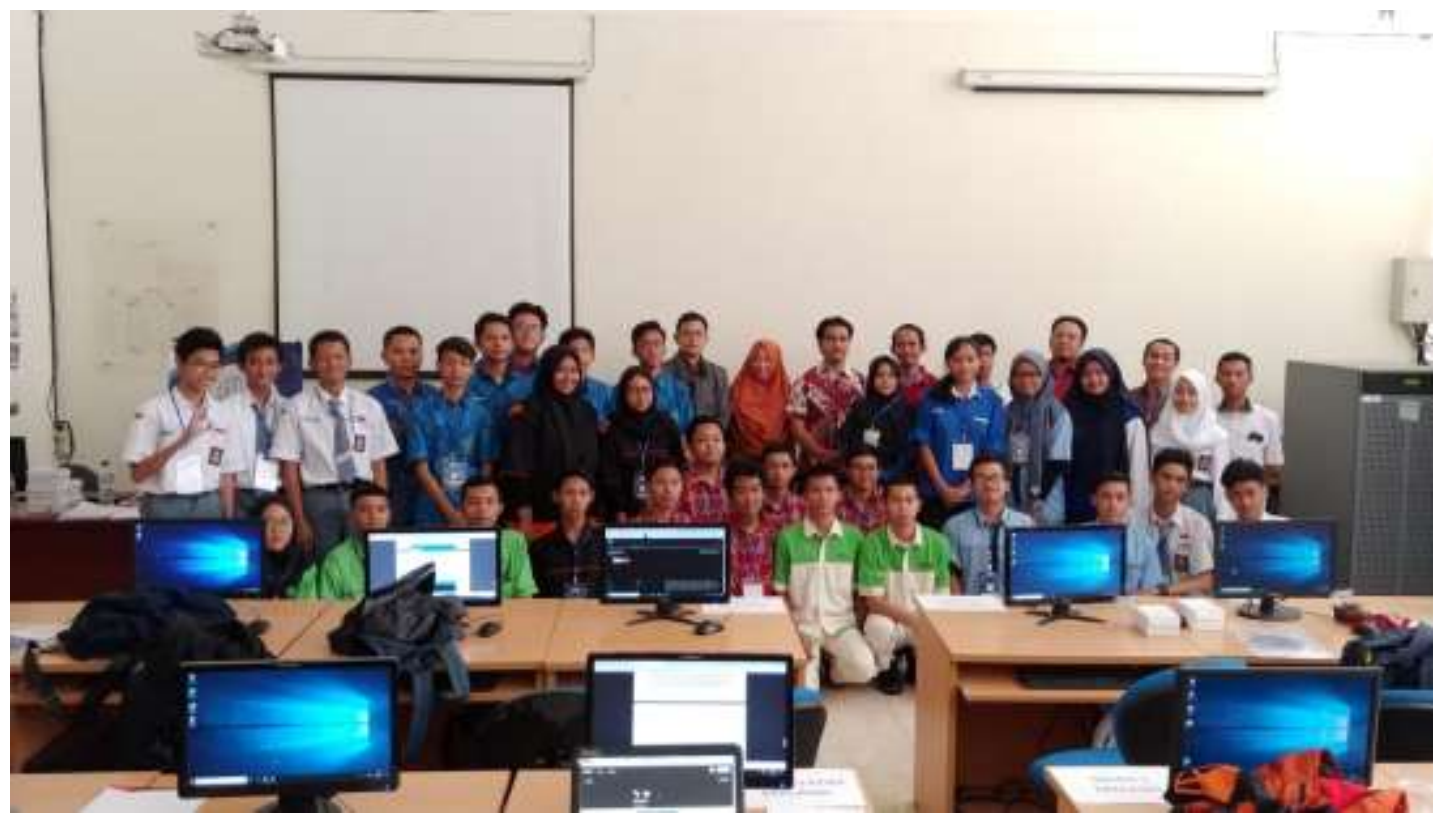

(e)

Gambar 1. (a) Dokumentasi Kegiatan sesi materi, (b) sesi workshop, (c) modul perangkat, (d) sesi tanya jawab dan diskusi, (e) sesi foto bersama 
Grafik perbandingan nilai evaluasi peserta ditampilkan pada Gambar 2. Dari grafik dapat dilihat bahwa nilai peserta rata-rata meningkat. Nilai pre-test memiliki rata-rata 61,6 sedangkan nilai post-test rata-rata 92,9 atau memiliki kenaikan nilai sebesar 31,3. Dapat disimpulkan bahwa pelatihan mampu meningkatkan pemahaman dan ketrampilan peserta di bidang IoT. Sebelum pelatihan dimulai, range nilai peserta adalah antara 50-90. Sedangkan di akhir pelatihan, nilai peserta adalah 80-100. Nilai minimal post-test adalah 80, hal tersebut menunjukkan bahwa kemampuan terendah peserta di akhir pelatihan sudah sangat tinggi dalam hal pemahaman robotika. Grafik tersebut menunjukkan setiap peserta mengalami peningkatan pemahaman sesudah mengikuti pembelajaran dan praktek yang diberikan. Peningkatan nilai tersebut bervariasi antara 10-50 poin.

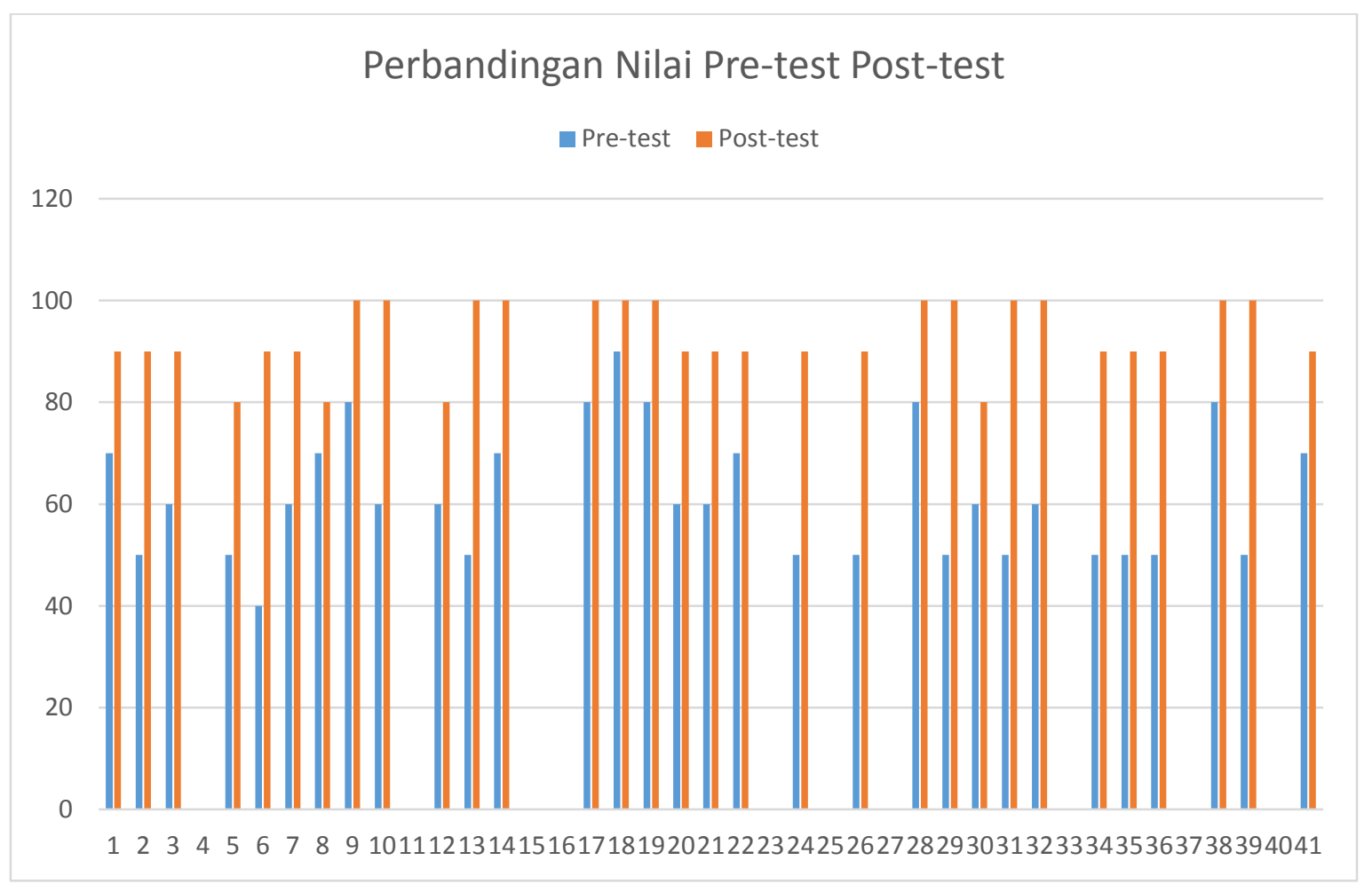

Gambar 2. Grafik perbandingan nilai setiap peserta

\subsection{Hasil evaluasi pelaksanaan pelatihan}

Selain menguji kemampuan peserta dalam pemahaman dan ketrampilan IoT, evaluasi juga diselenggarakan dalam hal pelaksanaan pelatihan. Evaluasi dilakukan dengan memberikan kuisioner yang terdiri dari aspek pelatihan yakni:
a) Persiapan Kegiatan
b) Pelaksanaan Kegiatan:
c) Kesesuaian jadwal
d) Kesesuaian tempat
e) Kesesuaian fasilitas (Arduino, ESPS8266 breakout board)
f) Kualitas materi yang diberikan
g) Kualitas pemateri
h) Evaluasi Kegiatan

Kuisioner berisi 4 pertanyaan dengan masing-masing 5 skala jawaban dari SS = sangat setuju, $\mathrm{S}$ = setuju, TS = tidak setuju, STS = sangat tidak setuju. Dari ke-4 pertanyaan, modus atau mode dari jawaban peserta adalag $S$ atau Setuju terhadap indikator pelatihan yang baik. Dari total 425 jawaban, terdapat 17 jawaban STS (15 bernilai positif, 2 bernilai negatif), 39 jawaban TS (31 bernilai positif, 6 bernilai negatif), 205 jawaban S dan 164 jawaban SS. Dengan memperhitungkan 
komponen positif dan negatif, maka didapatkan rekapitulasi sebesar $15+31+205+164=415$ responden (98\%) menilai puas pada keberhasilan penyelenggaraan kegiatan. Hal ini dapat disimpulkan bahwa pelatihan telah sesuai dengan harapan peserta tentang penyelenggaraan pelatihan yang mudah dipahami, mudah dipraktekkan dan memuaskan.

\section{KESIMPULAN}

Dalam Kemajuan pelaksanaan Pengabdian Masyarakat ini dapat disimpulkan bahwa:

1. Kegiatan pengabdian masyarakat berupa pelatihan dalam rangka peningkatan kompetensi keilmuan IoT yakni tentang pengontrolan perangkat IoT dengan menggunakan Smartphone untuk Siswa SMK maupun SMA sederajat dilakukan dalam format berupa pemberian teori dan praktek yang dilaksanakan guna meningkatkan pemahaman, ketrampilan serta antusiasme siswa SMK-SMA sederajat di Malang dalam bidang IoT

2. Pelatihan yang diberikan mampu meningkatkan pemahaman dan ketrampilan peserta di bidang IoT sebesar $26.07 \%$ dari evaluasi pre-test post-test yang diberikan. Pelatihan juga diterima dengan baik oleh peserta dimana ditunjukkan melalui hasil kuisioner evaluasi pelaksanaan kegiatan dengan nilai kepuasan sebesar 98\% terhadap indikator-indikator yang disampaikan dalam pelatihan.

3. Saran-saran kegiatan pengabdian masyarakat lebih lanjut ditujukan untuk mengevaluasi, menutup kekurangan, serta meningkatkan kualitas kegiatan pengabdian masyarakat selanjutnya, yakni membuat roadmap pelatihan yang lebih spesifik agar tiap tahun dapat dilakukan tracing sejauh mana keilmuan bidang tertentu telah disebarkan. Selain itu, untuk meningkatkan minat peserta, kegiatan dapat juga dibuat dalam bentuk kompetisi teknis yang dilakukan setelah workshop dilaksanakan

\section{UCAPAN TERIMA KASIH}

Penulis mengucapkan terima kasih kepada Fakultas Ilmu Komputer Universitas Brawijaya yang telah memberi dukungan bagi terlaksananya kegiatan pengabdian ini melalui skema hibah kegiatan pengabdian DIPA 2019. Penulis juga berterima kasih kepada seluruh pihak, utamanya mitra sekolah dan juga segenap panitia mahasiswa yang berpartisipasi aktif dalam kegiatan ini.

\section{DAFTAR PUSTAKA}

Afshar, V. (2017). Cisco: Enterprises Are Leading The Internet of Things Innovation. HuffPost. https://www.huffingtonpost.com/entry/cisco-enterprises-are-leading-the-internet-ofthings_us_59a41fcee4b0a62d0987b0c6

Deborah Fallows. (2004). The Internet and Daily Life / Pew Research Center. Pew Research Center. https://www.pewresearch.org/internet/2004/08/11/the-internet-and-dailylife/\%0Ahttp://www.pewinternet.org/2004/08/11/the-internet-and-daily-life/

Dharmawati, D. (2020). Pembelajaran Berbasis Komputer Menggunakan Ms. Office 2019 Pada Siswa di SMK Dwitunggal 1 Tanjung Morawa. Dinamisia: Jurnal Pengabdian Kepada Masyarakat. https://doi.org/10.31849/dinamisia.v4i1.3751

Ginanjar Wiro Sasmito. (2020). Studi Pengenalan Internet Of Things Bagi Guru Dan Siswa SMK Bina Nusa Slawi Sebagai Wawasan Salah Satu Ciri Revolusi Industri 4.0. Dinamisia : Jurnal Pengabdian Kepada Masyarakat. https://doi.org/10.31849/dinamisia.v4i1.3692

Guntoro, G., Costaner, L., \& Sutejo, S. (2017). Pelatihan Sistem Pembelajaran E-Learning Pada Sekolah Menengah Kejuruan Dwi Sejahtera Pekanbaru. Dinamisia: Jurnal Pengabdian Kepada Masyarakat. https://doi.org/10.31849/dinamisia.v1i1.411

Kumar, S., \& Lee, S. R. (2014). Android based smart home system with control via Bluetooth and internet connectivity. Proceedings of the International Symposium on Consumer Electronics, ISCE. https://doi.org/10.1109/ISCE.2014.6884302 
Lukman, H. S. (2015). Mengembangkan Potensi Wirausaha Siswa SMK 2 Muhammadiyah Melalui Pengelolaan Business CenteR. Jurnal Surya: Seri Pengabdian Masyarakat, 1(1).

Mtshali, P., \& Khubisa, F. (2019). A smart home appliance control system for physically disabled people. 2019 Conference on Information Communications Technology and Society, ICTAS 2019. https://doi.org/10.1109/ICTAS.2019.8703637

Nuris, D. M. (2018). Pelatihan Penyusunan Perangkat Pembelajaran Berbasis TIK Bagi Guru Akuntansi SMK. Dinamisia: Jurnal Pengabdian Kepada Masyarakat. https://doi.org/10.31849/dinamisia.v2i2.1819

Rose, K., Eldridge, S., \& Chapin, L. (2015). The Internet Of Things: An Overview. Understanding the Issues and Challenges of a More Connected World. The Internet Society, October, 80. https://doi.org/10.5480/1536-5026-34.1.63 